\title{
The method of valorisation of trees according to their biocenotic values
}

\section{Lidia Ozimkowska, Jerzy Wojtatowicz}

\begin{abstract}
The article presents a method of tree valorisation according to their biocenotic values. Three categories of descriptive and numerical evaluation of the biocenotic value of a tree were proposed. They result from individual features, connections to the immediate surroundings and location in regard to the discussed object and neighbouring ecosystems.

The sum of points obtained by a tree in the three categories is the basis for qualifying to one of the biocenotic value groups.
\end{abstract}

Key words: landscape architecture, dendrology, valorisation, biocenotic values of trees, natural connections

\section{Introduction}

Trees are evaluated in many ways depending on the goal to be achieved. Therefore, some of them are rated as trees of particular importance. In order to select, from the tree stand, trees of special value different types of inventories must be carried out. Various methods are used in landscape architecture, including those used by specialists in other industries. The article presents the methods of tree inventory and evaluation used so far and points out the need to extend the evaluation of trees due to the deteriorating conditionof the natural environment and minimalist design trends. Implementation of proposed changes in the way of tree valorisation may contribute to a broader view of the problems of protection and exposing special trees, which is especially important in landscape architecture facilities.

The values of trees have always been appreciated and evaluated. ${ }^{1}$ The rich symbolism and material values of selected species made it necessary to identify and valorise them, which has subsequently been developed in various branches of the economy, such as horticulture, gardening, forestry, carpentry, boatbuilding, sculpting and many others. Trees growing in leisure facilities should fully serve such a purpose. Recreation, understood as a form of passive or active way of spending time, takes place in the scenery of living and inanimate

\footnotetext{
${ }^{1}$ People found in them: strength, shelter, food and useful materials; they were used for healing purposes and could also be a source of poison. The evergreen ones symbolized immortality, and the seasonal ones - rebirth. They protected against ghosts or lightning, commemorated important events and were the object of magic and worship.
} 
elements. The most noticeable living elements, mainly due to their large size, are trees.

The ones that stand out from the environment in terms of plasticity (e.g. form, color) or utility (e.g. fragrant flowers or tasty fruits) deserve to be called special. The usefulness of trees for other living organisms of flora and fauna is also not without significance [Luniak 2016; Luniak, Weggrzynowicz 2019]. Currently, the biocenotic values of trees are increasingly recognized [Wojtatowicz 1994, 2006], while there are a few studies relating to park trees, especially methodological and analytic studies. Such attempts have been made since the early 1980s as a part of outdoor exercises with students, as well as a part of project studies in historical parks [Ozimkowska, Wojtatowicz 2013, 2015, 2016 a, b, 2018].

In order to ensure that the spectrum of tree-related species that can be observed in arecreational area is as large as possible, it is essential to conduct a thorough, often laborious analysis of the existing condition of trees and their surroundings. In the design process, it is necessary to be aware of the consequences that any changes bring.

A field study in order to select and determine the value of plants significant for enrichment of the biocenosis (taking into account the leisure comfort of people) should be one of the basic activities if we want to preserve the highest possible biocenotic values.

Those trees that have high biocenotic values, and at the same time arouse human interest, are important from the designer's point of view. Usually, however, less attention is paid to trees that do not arouse admiration by their form, color or other features, even if they have high biocenotic values. Considerations on the biocenotic values of trees have been undertaken to draw attention to the essence of their presence in designed and nurtured areas.

\section{Goal and scope}

The aim of the article is to present the method of tree valorisation according to their biocenotic values. During the elaboration of this method, the individual features of trees and their connections with the surroundings inside and outside of the designed facility were identified. The method can be applied to different tree stands, especially in landscape architecture, in field of protection of trees with high biocenotic values.

\section{The definition of biocenotic plants}

The term has been used in forestry to refer to trees for a long time. As biocenotic trees foresters consider: "alive or dead trees, locally decayed, which are characterized, among others, by the following features: they are den trees of an unusual habit, there are hollows on them, they grow mosses, funguses, lichens, they stand out from its surroundings in terms of age or size and are a monument of forest culture"2, as well as "tree and shrub species introduced into the tree stands to provide a habitat for animals; they contribute to the maintenance and

\footnotetext{
${ }^{2}$ https://www.encyklopedialesna.pl/haslo/drzewa-biocenotyczne-1/
} 
enhance favourable biocenotic relations as well as the health and natural resistance of the forest". 3

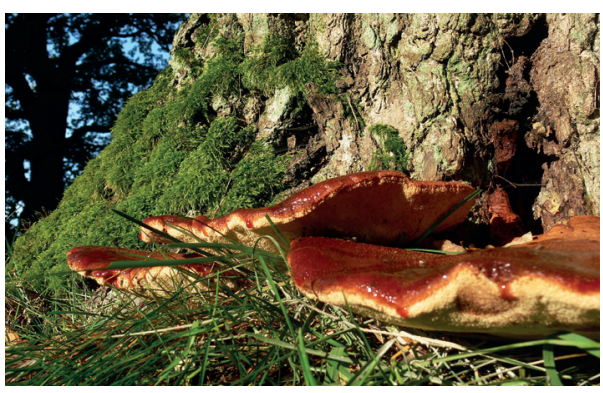

Over time, the term "biocenotic tree" has become more widely used. "Biocenotic tree - defective tree left in commercial forests to increase biodiversity. Biocenotic trees can be alive or dead. Biocenotic trees are trees with visible local decay, a hollow tree with a bird's nest over $25 \mathrm{~cm}$ in diameter, trees with more than $1 / 3$ of the crown dead, trees with polypores or plants, protected animals or funguses. Biocenotic trees are also trees of an unusual type or unusual morphological forms (deformed trunks, growths). Biocenotic trees also include trees that are monuments of forest culture (exotic specimens, experimental fields established before 1945, lanes, etc.). Biocenotic trees are also "downtime trees", i.e. trees left for the next cut. Native species that improve the feeding base for the game, nectar-producing, diversifying the landscape (apple tree, pear tree, cherry tree, alder plum and others) are also considered as biocenotic trees" ${ }^{4}$

Analysing the various sources, in which biocenotic trees are defined, it was found that the term refers to protected, rare and endangered species or that the tree is important for their life. Such an approach is the base of the assessment of tree values from the point of view of nature protection.

In the article, trees, shrubs and other biocenotic plants are considered to be of particular importance for the life and development of other organisms. These plants may provide habitat for other plants, funguses and lichens; provide food, shelter or be used as breeding or nesting sites for animals or to fullfil other life needs such as singing, drumming, or fighting during mating season. The value of these plants results both from the biological features of the species, individual characteristics and location in the landscape. Both the immediate vicinity and the location in relation to neighbouring ecosystems, even those located outside the boundaries of the studied object, are important. The considerations were focused on trees and shrubs, which are basic plant material for a landscape architect. Biocenotic trees and shrubs can fulfill one life need of other species over a short period of time or multiple needs, even over many years.

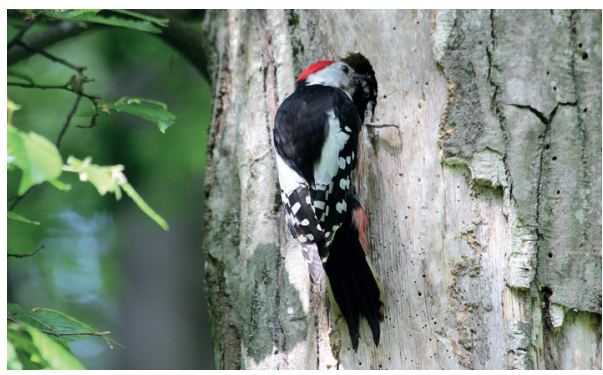

\footnotetext{
${ }^{3}$ https://www.lasy.gov.pl/pl/edukacja/slownik/g/gatunki-biocenotyczne

${ }^{4}$ https://pl.wikipedia.org/wiki/Drzewo_biocenotyczne
} 


\section{Trees that should be considered in the study}

When considering the biocenotic value of a tree, its suitability for one, even a very specific organism which is threatened with extinction (which could be the essence of the assessment of a tree from the point of view of nature protection), is not highly evaluated. The most important is the significance of the tree as a habitat for many species bonded with it either permanently or periodically. Nowadays, especially in cities, alive or dead biocenotic trees should be marked in inventories in order to preserve them for increasing biodiversity. On the grounds that the location of such trees often has a significant impact on the biocenotic value and sometimes on the safety of users, it is important to consider this value in assessments in relation to the context of the surrounding environment. When assessing the usefulness of a particular tree or shrub for a biocenosis, it may be concluded that some of them provide more food for a large group of animals, e.g. rowan fruits, apple trees; others - shelter; others create many convenient sites for procreation by nature, e.g. magnificent oaks, lindens, chestnut trees, Norway maple - type "Globosum" and some others have all these features together, e.g. elderberry, grapevine. However, these features are not the basis for distinguishing a species as biocenotic because even species that produce seeds and fruits, that animals eat, may not produce them in particular place. That is why a reliable inventory of trees, extended by their valorisation from the biocenotic point of view, seems to be so important. When considering the importance of dead trees in landscape architecture of facilities, especially those located in urban areas or historical parks, where care was taken to ensure that all dead branches and limbs were removed, it should be stated that if there are no forest nature reserves and other objects with dead wood in their surroundings, each decaying trunk left behind is of great biocenotic importance for life or inhabitance of rare species in this environment. However, not all dead trunks have high biocenotic values. Also short-lived, fast-growing plants and many light-growing plants with a relatively low market value, introduced to a park as so called "forecrop" at a given stage of park development, may be considered biocenotically valuable as long as they meet the described requirements. It should be noted that these trees were designed to be removed at a certain level of development of a park and when making such a decision their biocenotic value should be reassessed, considering the possibility of leaving them. If their retention will definitely interfere with the park's development goals, then they should be cut down and their trunks possibly left

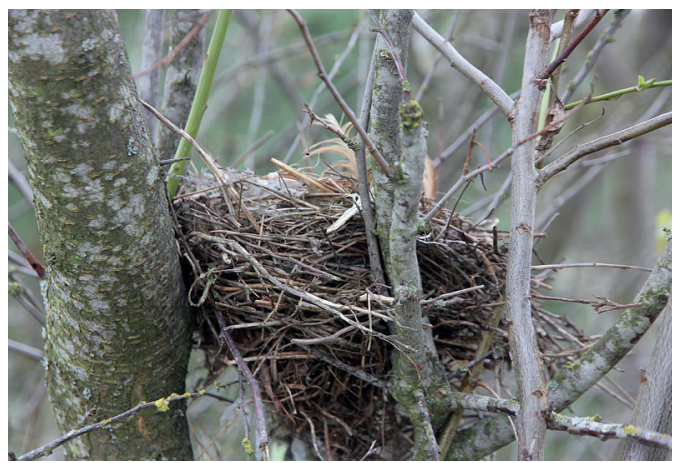
to decay. 


\section{Functions of biocenotic plants in landscape architecture}

For a landscape architect, plants that attract animals are important because of their impact on the comfort of people's recreation. Trees with high biocenotic values are attractive to a wide variety of species, which ultimately increases a recreational value of an area. Recreation involving communing with nature is highly valued, especially in large cities. Observing funguses, lichens, butterflies and other insects, reptiles, amphibians,

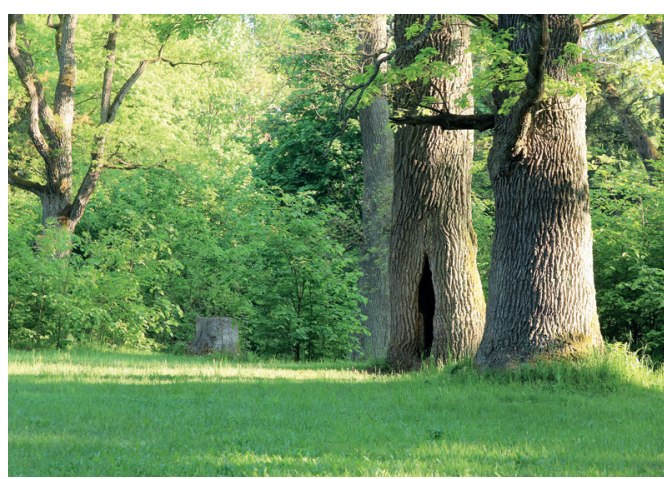
birds and mammals that use trees, as well as their movements, sounds, and other life activities is of high cognitive importance and usually gives pleasure [Ozimkowska, Wojtatowicz J., Wojtatowicz T. 2017].

In addition, trees and shrubs considered biocenotic are most often old, with a characteristic picturesque shape with high functional values (e.g. strengthening slopes, forecrop on reclaimed areas) and often also with high aesthetic values.

\section{Inventory and tree assessment in landscape architecture}

The value of trees in landscape architecture of facilities is assessed in many aspects, e.g. historical, nature protection and, above all, safety for users, which is related to their health condition. The assessment most often determines the species, then basic dendrometric measurements are taken (trunk circumference, crown diameter and height). The trunk circumference and the crown diameter are measured with a measuring tape at a height of $130 \mathrm{~cm}$ above ground surface, with an accuracy of $1 \mathrm{~cm}$ for the trunk and $0.5 \mathrm{~m}$ for the crown. The height is measured with an altimeter with an accuracy of $0.5 \mathrm{~m}$. During the visual inspection of the health condition of trees and shrubs, attention is paid to the condition of the trunk (decay slats, surface defects and cavities, mechanical damage, decay, signs of insect feeding, signs of woodpeckers feeding, fungal fruiting bodies, tilt of the trunks, etc.) and the crown (dry branches, broken branches, hollows, presence of mistletoe, asymmetry, reduction).

In the process of selecting trees for removal, it is checked whether they are a niche, habitat or refuge for small but valuable animal species; do they have nests or hollows in which legally protected animals live. They are assessed in terms of colonization by species: protected funguses, lichens, mosses, ferns. The general health condition is usually determined on a three-point scale (good, average, bad), where: 
- good - tree of normal shape, correctly formed crown, slight wither of the crown up to $20 \%$;

- medium - tree of abnormal shape, crown often deformed, e.g. the main momentum cut off, one-sided crown, etc., possibility of decay, wounds, etc., wither 20-40\%;

- bad - tree with a strongly deformed crown, with cavities in the trunks and branches,

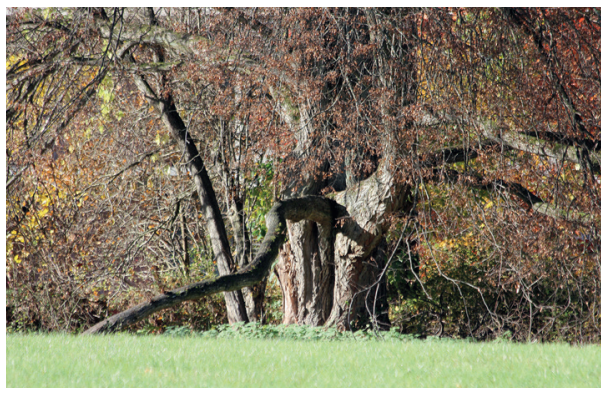
often dying, wither above $40 \%$.

The photos, taken by J. Wojtatowicz, present examples of biocenotic trees.

\section{Proposed method of tree assessment in terms of biocenotic value in landscape architecture of facilities}

Understanding the complexity of research problems, which may result from the definitions of biocenosis ${ }^{5}$ or biocenotic trees, the authors limit the assessment to trees and easily noticeable elements that are closely related to it. Food dependencies and various other ecological factors, easily observable in the area and which have a practical aspect, should be considered in the assessment in order to preserve as much as possible of the existing natural connections. These should be included in the design process (incl. revalorisation ) and used during construction or long-term maintenance of a facility. When assessing value of trees from different points of view, there is a need to retain the most valuable ones. As already mentioned, the most important trees are those, which in terms of functionality and composition, enable the implementation of a specific leisure program that meets the set goals. In historical parks and gardens under legal protection, it is important to preserve the historical values while providing the highest possible comfort for users. Similarly, recreational functions are equivalent to nature functions in most ecological or didactic parks, in botanical, zoological and ethnographic gardens. In typical landscape architecture of facilities, if a tree is of high value to meet a priority goal, regardless of its biocenotic value, it will certainly be preserved.

In order to preserve trees of high biocenotic value, they should be subjected to valorisation. The assessment of the biocenotic value of trees enables making aware decisions not only in relation to trees with the highest individual values, but also to trees and their surroundings, in which there are close natural connections. In the method described below, on the

\footnotetext{
${ }^{5}$ Biocenosis (gr. bios - life and koinós - common) - a group of populations of plant organisms (phytocenosis), animal (zoocenosis) and microorganisms (microbiocenosis) of a particular environment (biotope), belonging to different species, but related to each other by various ecological factors and food dependencies, forming unity, which remains in nature in the state of homeostasis (i.e. dynamic equilibrium) [Wikipedia].
} 
basis of observation, it is easy to determine whether a tree is dead or alive; bears fruit abundantly and the fruit is eagerly eaten by various animal species; has thinned crown, noticable fungal fruiting bodies, lichens, nests or places suitable for nests, hollows or other places for procreation. You can tell by sense of hearing if there is a bird's breeding habitat.

In the course of field research it is possible to determine how strongly it is connected with its surroundings and whether the connections and dependencies with the elements of its neighbourhood are strong or weak, and whether its presence affects the immediate surroundings and biocenosis. In the presented method, three categories of tree biocenotic value assessment were distinguished (Tables 1-3):

A - derived from its individual features (biological and acquired);

$\mathrm{B}$ - derived from the connections with the immediate surroundings;

$\mathrm{C}$ - derived from the location in the facility and location in relation to ecosystems, incl.

beyond its boundaries.

Alive or dead trees are assessed. A tree can achieve a maximum of 3 points in each category. A total of 9 points is obtained by summing up the highest points from the three categories. The minimum total score is 3 points. The points correspond to the descriptive and numerical assessment that a tree can obtain during the valorisation in the area. The total number of points that a tree gets is the basis for qualifying it into one of the three groups (I-III), where: I - trees with the lowest value (3 points), II - trees with an average value (4-6 points), III - trees with the highest value (7-9 points).

In the tables below, the word "park" is used symbolically and abbreviated and refers to different studied facilities.

Table 1. Assessment of the biocenotic value of a tree, in descriptive and numerical form, derived from its biological and acquired features

\begin{tabular}{|l|c|}
\hline \multicolumn{1}{|c|}{ A - Biocenotic value of a tree due to individual features } & Points \\
\hline $\begin{array}{l}\text { Tree unattractive as a habitat for plants, funguses and lichens, interferes } \\
\text { with the development of the formed biocenosis of the park. Crown thinned. }\end{array}$ & \\
Lack of hollows and other places usable for shelter, breeding and procreation \\
of animals of considerable size. Low value in terms of benefits, especially \\
food for animals. The species is a threat to fauna and flora, beneficial for \\
the development of the park, as well as the elements of the compositional \\
arrangement.
\end{tabular}




\begin{tabular}{|c|c|}
\hline A - Biocenotic value of a tree due to individual features & Points \\
\hline $\begin{array}{l}\text { Tree attractive as a habitat for many plants, funguses and lichens. It is an } \\
\text { element of the formed biocenosis of the park. Crown and trunk with hollows, } \\
\text { usable for building nests and other places of procreation and shelter for } \\
\text { animals of considerable size. High value in terms of benefits, and especially } \\
\text { food for animals. }\end{array}$ & 3 \\
\hline
\end{tabular}

The proposed method can be extended by assessing special trees for which the determination of biocenotic value is a priority in a particular area, e.g., legally protected in terms of history or nature. In this case, a five-point rating scale is proposed (Tables 4-6).

A tree can achieve a maximum of 5 points in each category. A total of 15 is obtained by summing up the highest points from the three categories. The minimum total score is 3 points. The points correspond to the descriptive and numerical assessment that a tree can obtain during the valorisation in the area. The total number of points that a tree gets is the basis for qualifying it into one of the five groups (I-V), where: I - trees with the lowest value, II - trees with sufficient value (4-6 points), III - trees with an average value (7-9 points), IV - trees with high value (10-12 points) and V - trees with the highest value (13-15 points).

Table 2. Assessment of the biocenotic value of a tree, in descriptive and numerical form, derived from the connections with the immediate surroundings

\begin{tabular}{|l|c|}
\hline \multicolumn{1}{|c|}{$\begin{array}{c}\text { B - Biocenotic value of a tree assessed on the basis of its connections with } \\
\text { the immediate surroundings }\end{array}$} & Points \\
\hline $\begin{array}{l}\text { It is one of the elements of a monoculture cluster with a low biocenotic } \\
\text { value. Many elements of the environment, anthropopressive factors and } \\
\text { care treatments carried out here have a negative influence on the biocenotic } \\
\text { value of a tree and the existing beneficial connections between the tree and } \\
\text { its surroundings. }\end{array}$ & 1 \\
\hline $\begin{array}{l}\text { It is one of the elements of a monoculture cluster with an average biocenotic } \\
\text { value. Many elements of the environment, anthropopressive factors and } \\
\text { care treatments carried out here do not significantly influence the biocenotic } \\
\text { value of a tree and the existing beneficial connections between the tree and its } \\
\text { surroundings. }\end{array}$ & 2 \\
\hline $\begin{array}{l}\text { Grows in an environment with high biocenotic value. Many elements of the } \\
\text { environment and the care treatments carried out increase the biocenotic value } \\
\text { of the tree. }\end{array}$ & 3 \\
\hline
\end{tabular}


Table 3. Assessment of the biocenotic value of the tree, in descriptive and numerical form, derived from the location in the park and location in relation to ecosystems outside the park

\begin{tabular}{|l|c|}
\hline $\begin{array}{l}\text { C-Biocenotic value of a tree due to the location in the park and location in } \\
\text { relation to ecosystems outside the park }\end{array}$ & Points \\
\hline $\begin{array}{l}\text { A tree with a low biocenotic value, located in the intensive penetration } \\
\text { zone by park users. It grows in a center of a large city, onerous industrial } \\
\text { areas, very busy roads or other areas subjected to strong anthr opopressure. }\end{array}$ & \\
$\begin{array}{l}\text { It can be a tree of high biocenotic value, which makes it a trap for animals by } \\
\text { attracting them, e.g. by providing abundant and attractive food; by growing } \\
\text { in the close proximity to busy roads, it poses a threat. For this reason, it is } \\
\text { rated like other low-value trees. }\end{array}$ & 1 \\
\hline $\begin{array}{l}\text { A tree with an average biocenotic value, located in a zone of moderate } \\
\text { penetration by humans. Its biocenotic value has no practical significance for } \\
\text { the ecosystems located outside the park. }\end{array}$ & 2 \\
\hline $\begin{array}{l}\text { A tree with high biocenotic value, located in the zone of minimal penetration } \\
\text { by humans. It is a valuable component of the park's biocenosis, and in some } \\
\text { cases - ecosystems outside the park. }\end{array}$ & 3 \\
\hline
\end{tabular}

Table 4. Assessment of the biocenotic value of a tree, in descriptive and numerical form, derived from its biological and acquired features

\begin{tabular}{|l|c|}
\hline \multicolumn{1}{|c|}{ A - Biocenotic value of a tree due to individual features } & Points \\
\hline $\begin{array}{l}\text { The tree is very unattractive as a habitat for plants, funguses and lichens; } \\
\text { interferes with the development of the formed biocenosis of the park. Crown } \\
\text { thinned. Lack of hollows and other places usable for shelter, breeding and } \\
\text { procreation of animals of considerable size. Very low value in terms of } \\
\text { benefits, especially food for animals. The species is a threat to fauna and flora, } \\
\text { beneficial for the development of the park, as well as the elements of the } \\
\text { compositional arrangement. }\end{array}$ & 1 \\
\hline $\begin{array}{l}\text { The tree is unattractive as a habitat for plants, funguses and lichens; it slightly } \\
\text { interferes with the development of the formed biocenosis of the park. Crown } \\
\text { thinned. Lack of hollows and other places usable for shelter, breeding and } \\
\text { procreation of animals of considerable size. Low-value in terms of benefits, }\end{array}$ & 2 \\
especially food for animals.The species is a minor threat to fauna and flora, \\
beneficial for the development of the park, as well as the elements of the \\
compositional arrangement.
\end{tabular}




\begin{tabular}{|l|c|}
\hline \multicolumn{1}{|c|}{ A - Biocenotic value of a tree due to individual features } & Points \\
\hline $\begin{array}{l}\text { The tree is moderately attractive as a habitat for plants, funguses and } \\
\text { lichens; it does not does significantly affect the development of the formed } \\
\text { biocenosis of the park. Limited number of places usable for shelter, breeding } \\
\text { and procreation of animals of considerable size. The species does not have }\end{array}$ & 3 \\
a significant impact on fauna and flora beneficial for the park's development, \\
especially on the elements of the compositional arrangement. Average value \\
in terms of benefits, especially food for native animal species.
\end{tabular}

Table 5. Assessment of the biocenotic value of a tree, in descriptive and numerical form, derived from the connections with the immediate surroundings

\begin{tabular}{|l|c|}
\hline $\begin{array}{l}\text { B - Biocenotic value of a tree assessed on the basis of its connections with } \\
\text { the immediate surroundings }\end{array}$ & Points \\
\hline $\begin{array}{l}\text { It is one of the elements of a monoculture cluster with a very low biocenotic } \\
\text { value. Many elements of the environment, anthropopressive factors and care } \\
\text { treatments carried out here have a very negative influence on the biocenotic } \\
\text { value of a tree and the existing beneficial connections between the tree and }\end{array}$ & 1 \\
its surroundings. & \\
\hline $\begin{array}{l}\text { It is one of the elements of a monoculture cluster with a low biocenotic } \\
\text { value. Many elements of the environment, anthropopressive factors and } \\
\text { care treatments carried out here have a negative influence on the biocenotic } \\
\text { value of a tree and the existing beneficial connections between the tree and its } \\
\text { surroundings. }\end{array}$ & 2 \\
\hline
\end{tabular}




\begin{tabular}{|c|c|}
\hline $\begin{array}{l}\text { B - Biocenotic value of a tree assessed on the basis of its connections with } \\
\text { the immediate surroundings }\end{array}$ & Points \\
\hline $\begin{array}{l}\text { It is one of the elements of a monoculture cluster with an average biocenotic } \\
\text { value. Many elements of the environment, anthropopressive factors and } \\
\text { care treatments carried out here do not significantly influence the biocenotic } \\
\text { value of a tree and the existing beneficial connections between the tree and its } \\
\text { surroundings. }\end{array}$ & 3 \\
\hline $\begin{array}{l}\text { Grows in an environment with high biocenotic value. Many elements of the } \\
\text { environment and the care treatments carried out increase the biocenotic value } \\
\text { of the tree. }\end{array}$ & 4 \\
\hline $\begin{array}{l}\text { Grows in an environment with very high biocenotic value. Many elements of } \\
\text { the environment and the care treatments carried out exceptionally increase } \\
\text { the biocenotic value of the tree. }\end{array}$ & 5 \\
\hline
\end{tabular}

Table 6. Assessment of the biocenotic value of the tree, in descriptive and numerical form, derived from the location in the facility and location in relation to ecosystems outside the park

\begin{tabular}{|l|c|}
\hline $\begin{array}{l}\text { C- Biocenotic value of a tree due to the location in the facility and location } \\
\text { in relation to ecosystems outside the park }\end{array}$ & Points \\
\hline $\begin{array}{l}\text { A tree with a very low biocenotic value, located in the intensive penetration } \\
\text { zone by park users. It grows in a center of a large city, onerous industrial } \\
\text { areas, very busy roads or other areas subjected to strong anthropopressure. } \\
\text { It can be a tree of high biocenotic value, which makes it a trap for animals by } \\
\text { attracting them, e.g. by providing abundant and attractive food; by growing }\end{array}$ & 1 \\
$\begin{array}{l}\text { in the close proximity to busy roads, it poses a threat. For this reason, it is } \\
\text { rated like other low-value trees. }\end{array}$ & 2 \\
\hline $\begin{array}{l}\text { A tree with a low biocenotic value, located in a zone of intensive penetration } \\
\text { by humans. Its biocenotic value has little significance for the ecosystems } \\
\text { located outside the park boundaries. }\end{array}$ & 2 \\
\hline $\begin{array}{l}\text { A tree with an average biocenotic value, located in a zone of moderate } \\
\text { penetration by humans. Its biocenotic value has no practical significance for } \\
\text { the ecosystems located outside the park. }\end{array}$ & 3 \\
\hline $\begin{array}{l}\text { A tree with high biocenotic value, located in the zone of non-intensive } \\
\text { penetration by humans. It is a valuable component of the park's biocenosis, } \\
\text { and in some cases - ecosystems outside the park. }\end{array}$ & 4 \\
\hline $\begin{array}{l}\text { A tree with very high biocenotic value, located in the zone of minimal } \\
\text { penetration by humans. It is an exceptionally valuable component of the } \\
\text { park's biocenosis, and in some cases - ecosystems outside the park. }\end{array}$ & 5 \\
\hline
\end{tabular}




\section{Summary}

The method described above can be classified as organoleptic. Such a method is imprecise and may also be questioned due to the hardly verifiable nature of the assessment. However, if performed accurately, it distinguishes trees with their surroundings, with different biocenotic values, which is sufficient for the design process. As a consequence, it allows to maintain the highest possible biocenotic values of the entire facility under given conditions. The article indicates a possible direction of transformations in pre-design works. Practical application of the research described in the article may contribute to a broader look at the problems of protecting and exhibiting biocenotic trees in landscape architecture facilities.

\section{References}

Luniak M., 2016, Projekt "Przyroda Parku Skaryszewskiego" w latach 2014-2015 [in:] J. Romanowski (ed.), Park Skaryszewski w Warszawie - przyroda i użytkowanie, Wydawnictwo Uniwersytetu Kardynała Stefana Wyszyńskiego, Warszawa.

Luniak M., Węgrzynowicz A., 2019, Wpływ renowacji parków miejskich na ich awifaunę lęgowqprzykład z Warszawy, Chrońmy Przyrodę Ojczysta, 75, 1, pp. 3-15.

Ozimkowska L., Wojtatowicz J., 2013, Projekt koncepcyjny zagospodarowania "Strefy natury" w Ogrodzie Krasinskich w Warszawie, Miasto Stołeczne Warszawa - zlecenie Zarządu Terenów Publicznych ul. Podwale 23, 00-261 Warszawa.

Ozimkowska L., Wojtatowicz J., 2015, Ekspertyza dotycząca sposobu zagospodarowania fragmentu Terenu Przy Dworze Polskim w Potworowie, zlecenie prywatne, archiwum Aster-Park.

Ozimkowska L., Wojtatowicz J., 2016 a, Ekspertyza dotyczaca sposobu zagospodarowania Parkupodworskiego w Podhorcach na Ukrainie, zlecenie prywatne, archiwum Aster-Park.

Ozimkowska L., Wojtatowicz J., 2016 b, Zespót dworsko-parkowy „Willa Mindic” jako szczególny element w krajobrazie i przemiany jego struktury jako znaków czasu, MAZOWSZE Studia Regionalne, 18, Mazowieckie Biuro Planowania Regionalnego, Warszawa, pp. 49-69.

Ozimkowska L., Wojtatowicz J., Wojtatowicz T., 2017, Correlations Between Birds, Plants and People in Urban Landscaping, Kaunas Forestry and Environmental Engineering University of Applied Sciences (KMAIK), Department of Landscape Architecture and Recreation, 1, 12. pp. 55-68.

Ozimkowska L., Wojtatowicz J., 2018, Adaptacja założenia dworsko-parkowego w Piekartach, MAZOWSZE Studia Regionalne, 27, Mazowieckie Biuro Planowania Regionalnego, Warszawa, pp. 103-121. 
Wojtatowicz J., 1994, Avifauna miejskich parków historycznych [in:] Materiały Sympozjum „Dziedzictwo miejskich ogrodów i krajobrazu historycznego", Katedra Urządzania i Pielęgnowania Krajobrazu SGGW, Ośrodek Ochrony Zabytkowego Krajobrazu, Warszawa Ursynów.

Wojtatowicz J., 2006, Theorical Basis for the Biocenotical Park System [in:] Starovinni parkì i botaniki badi-naukovì centri zberežennâ bìorizznomanittâ ta ohorona istoriko-kul" turnoï spadŝini. Nacìonal"na academìa nauk Ukraïni. Nacìonal"nij dendrologìcnij park "Sofï̈vka" - NDI NAN Ukraïni. Materìali mìžnarodnoï naukovoï konferenciï prisvivâčenoï 210-riččû Nacìonal”nogo dendrologičnogo parku "Sofïvvka" - NDI NAN Ukraïni, pp. 40-46.

\section{Websites}

https://www.encyklopedialesna.pl/haslo/drzewa-biocenotyczne-1/ [access 21.06.2019]

https://www.lasy.gov.pl/pl/edukacja/slownik/g/gatunki-biocenotyczne [access 21.06.2019]

https://pl.wikipedia.org/wiki/Drzewo_biocenotyczne [access 21.06.2019] 


\section{THE METHOD OF VALORISATION OF TREES ACCORDING TO THEIR BIOCENOTIC VALUES \\ Lidia Ozimkowska, Jerzy Wojtatowicz}

\section{Metoda waloryzacji drzew ze względu na ich wartości biocenotyczne}

\section{STRESZCZENIE}

W artykule przedstawiono metodę waloryzacji drzew ze względu na ich wartości biocenotyczne. Zaproponowano opisową i liczbową ocenę wartości biocenotycznej drzewa w trzech kategoriach, które wynikaja z cech osobniczych, powiązań $\mathrm{z}$ najbliższym otoczeniem oraz położenia $\mathrm{w}$ stosunku do omawianego obiektu i sasiadujacych ekosystemów. Suma punktów, jaką uzyska drzewo z trzech kategorii jest podstawą kwalifikacji do jednej z grup wartości biocenotycznej.

Słowa kluczowe: architektura krajobrazu, dendrologia, waloryzacja, wartości biocenotyczne drzew, powiązania przyrodnicze

\footnotetext{
Lidia Ozimkowska, PhD, Engineer of Landscape Architecture. Graduate of the Warsaw University of Life Sciences (SGGW). Landscape designer of the Botanical Garden of the Polish Academy of Sciences in Powsin (1982-1999). Co-owner of the Aster-Park design studio since 1995. In the years 1995-2000 she collaborated with magazines: "Kwietnik"("Flower-bed") and "Ogrody"("Gardens") magazines. An academic teacher at the University of Ecology and Management in Warsaw since 1999. Author of the monograph entitled "Boundaries of Landscape Architectural Objects". Supervisor of several dozen diploma works. Member of the Association of Polish Architects (SARP) and the Polish Dendrology Society (PTD). NOT-SITO Appraiser (the Scientific and Technical Association of Horticultural Engineers and Technicians). University of Ecology and Management, Warszawa, Olszewska 12; e-mail: I.ozimkowska@gmail.com.

Lidia Ozimkowska, dr inż. arch. kraj. absolwentka Szkoły Głównej Gospodarstwa Wiejskiego w Warszawie. W latach 1982-1999 zatrudniona w Ogrodzie Botanicznym Polskiej Akademii Nauk w Warszawie - Powsinie na stanowisku projektanta, od 1995 r. współwłaścicielka pracowni projektowej Aster-Park, w latach 1995-2000 współpracowała z czasopismami „Kwietnik" i „Ogrody”, od 1999 pracuje jako nauczyciel akademicki w Wyższej Szkole Ekologii i Zarządzania w Warszawie, autorka monografii "Granice obiektów architektury krajobrazu", promotor kilkudziesięciu prac dyplomowych, członek SARP, PTD, rzeczoznawca NOT-SITO. Wyższa Szkoła Ekologii i Zarządzania, Warszawa, ul. Olszewska 12; e-mail: l.ozimkowska@gmail.com.
}

Jerzy Wojtatowicz, PhD, Engineer of Landscape Architecture. Graduate and long-time academic staff member of the Department of Landscape Architecture at the Warsaw University of Life Sciences (SGGW). Since 1997 he has been associated with the University of Ecology and Management in Warsaw, where he served as the Dean of the Faculty of Architecture between 2000 and 2014. He has also been running the Aster-Park design studio together with Lidia Ozimkowska since 1995. Co-author of "Ptaki w ogrodzie" (Birds in Your Garden) and a science editor of two book publications: "Warszawska Przyroda. Obszary i obiekty chronione" (Warsaw's Nature. Sites and Areas Under Protection) and "Przyroda Warszawy" (Nature in Warsaw) and co-author of a chapter "Natural and landscape complexes and lands used for environmental purposes" in a monograph entitled "Przyroda Bielan warszawskich" (Nature in the Warsaw District of Bielany). University of Ecology and Management, Warszawa, Olszewska 12; e-mail:jerzy.wojtatowicz@gmail.com.

Jerzy Wojtatowicz, dr inż. arch. kraj. absolwent i wieloletni pracownik naukowy Katedry Architektury Krajobrazu Szkoły Głównej Gospodarstwa Wiejskiego w Warszawie. Od 1997 r. pracownik Wyższej Szkoły Ekologii i Zarządzania w Warszawie, (w latach 2000-2014 Dziekan Wydziału Architektury), od 1995 r. współwłaściciel pracowni projektowej Aster-Park, współautor książki „Ptaki w ogrodzie”, redaktor naukowy książek: „Warszawska Przyroda. Obszary i obiekty chronione”, "Przyroda Warszawy” oraz współautor rozdziału „Zespoły przyrodniczo-krajobrazowe i tereny użytku ekologicznego” w monografii „Przyroda Bielan warszawskich". Wyższa Szkoła Ekologii i Zarządzania, Warszawa, ul. Olszewska 12; e-mail:jerzy.wojtatowicz@gmail.com. 